\title{
PENINGKATAN HASIL BELAJAR IPA MATERI TEMPAT HIDUP MAKHLUK HIDUP MELALUI PEMBELAJARAN AKTIF TIPE CARD SORT DI KELAS II SDN KETAWANG KARAY I KEC. GANDING KAB. SUMENEP SEMESTER 1 TAHUN PELAJARAN 2018/2019
}

\author{
Sayuti \\ SDN Ketawang Karay I \\ spdisayuti@gmail.com
}

\begin{abstract}
Abstrak
Penelitian ini dilakukan untuk meningkatkan hasil belajar peserta didik pada pembelajaran IPA materi tempat hidup makhluk hidup di kelas II SDN Ketawang Karay I Kecamatan Ganding Kabupaten Sumenep Semester 1 Tahun Pelajaran 2018/2019 melalui Strategi Pembelajaran Aktif Tipe Card Sort. Penelitian ini dilaksanakan pada peserta didik kelas II SDN Ketawang Karay I Kecamatan Ganding Kabupaten Sumenep saat pembelajaran IPA dengan materi tempat hidup makhluk hidup menggunakan Strategi Pembelajaran Aktif Tipe Card Sort. Rencana tindakan dalam penelitian ini akan dilaksanakan dalam 2 siklus dan direncanakan akan dilaksanakan dengan langkah perencanaan, tindakan, pengamatan, dan refleksi. Hasil penelitian menunjukkan bahwa pada pra siklus, kondisi hasil belajar peserta didik belum memuaskan baru terdapat $36 \%$ atau 5 orang peserta didik yang baru tuntas dalam pembelajaran dan sisanya 9 orang atau sekitar $64 \%$ peserta didik yang belum tuntas dengan rata-rata klasikal sebesar 47. Sehingga dilanjutkan perbaikan dengan menjelaskan dan menggunakan langkah-langkah pembelajaran dengan strategi pembelajaran aktif tipe card sort. Pada siklus I terdapat peningkatkan hasil belajar peserta didik yang cukup baik, dimana ada 9 orang peserta didik atau sekitar $64 \%$ yang tuntas dalam pembelajaran dan sisanya 5 orang peserta didik atau sekitar $36 \%$ peserta didik yang belum tuntas dengan rata-rata klasikal sebesar 73 . Kemudian pada siklus II, hasil belajar peserta didik mengalami peningkatan yang sangat signifikkan dimana 14 orang peserta didik semua tuntas atau $100 \%$ dalam pembelajaran dengan rata-rata klasikal sebesar 87. Hal ini menunjukkan bahwa dengan menggunakan strategi pembelajaran aktif tipe Card Sort dapat meningkatkan hasil belajar peserta didik pada pembelajaran IPA di kelas II SDN Ketawang Karay I Kecamatan Ganding Kabupaten Sumenep.
\end{abstract}

Kata Kunci : Hasil belajar, IPA, Strategi Pembelajaran Aktif , Card Sort

\begin{abstract}
This research was conducted to improve learning outcomes of students in science learning material where living things in class II Ketawang Karay I SDN Ganding Subdistrict Sumenep Regency 1st Semester 2018/2019 through the Card Sort Type Active Learning Strategy. This research was conducted on second grade students of Ketawang Karay I Elementary School in Ganding Subdistrict, Sumenep Regency during science learning with living things using living things using the Card Sort Type Active Learning Strategy. The action plan in this study will be carried out in 2 cycles and is planned to be carried out with steps of planning, action, observation, and reflection. The results showed that in the pre-cycle, the condition of student learning outcomes had not been satisfactory, there were only $36 \%$ or 5 new students completed in learning and the remaining 9 people or about $64 \%$ of students who had not completed the classical average of 47 . So that repairs are continued by explaining and using the learning steps with an active learning strategy type card sort. In the first cycle there was an increase in student learning outcomes that was quite good, where there were 9 students or about $64 \%$ who completed the learning and the remaining 5 students or about $36 \%$ of students who have not completed the classical average of 73. Then in the second cycle, the learning outcomes of students experienced a very significant increase in which 14 students all completed or $100 \%$ in learning with a classical average of 87. This shows that using the Card Sort type active learning strategies can improve learning outcomes students in science learning in class II Ketawang Karay I Elementary School Ganding District Sumenep Regency.
\end{abstract}

Keywords: Learning Outcomes, Science, Active Learning Strategies, Card Sort 
Sayuti

\section{Pendahuluan}

Dalam proses belajar mengajar Kelas II SDN Ketawang Karay I Kecamatan Ganding Kabupaten Sumenep Semester 1 terhadap pelajaran IImu Pengetahuan Alam dalam materi tempat hidup mkhluk hidup, hanya 5 peserta didik dari 14 peserta didik atau $36 \%$ yang mencapai ketuntasan dalam pembelajaran sedangkan 9 peserta didik atau 64\% tidak tuntas dengan KKM 70.

Berdasarkan hal tersebut, peneliti meminta bantuan teman sejawat untuk mengidentifikasi kekurangan dari pembelajaran yang dilaksanakan. Terungkap beberapa masalah ketika pembelajaran berlangsung diantaranya:

a. Hasil belajar IPA peserta didik kelas II masih rendah yakni di bawah KKM 70, dari 14 peserta didik hanya 5 peserta didik (36\%) tuntas sedangkan 9 peserta didik (64\%) belum tuntas.

b. Rata-rata tes hasil belajar peserta didik masih rendah, hanya 47.

c. Kemampuan berpikir rasional peserta didik sangat rendah

d. Peserta didik kurang aktif dan cenderung pasif

e. Motivasi belajar peserta didik masih rendah

Terkait penyebab rendahnya hasil belajar IPA dari peserta didik, teman sejawat menyampaikan temuan sebagai berikut.

a. Guru hanya mengunakan media gambar dalam proses pembelajaran.

b. Aktifitas peserta didik sangat kurang karena hanya mendengarkan guru berbicara menyampaikan materi

c. Guru hanya menggunakan metode ceramah dan peran guru sangat dominan.

d. Alat peraga kurang menunjang dalam proses pembelajaran.

e. Pertanyaan terlalu sulit untuk dipahami oleh peserta didik.

Berangkat dari masalah-masalah yang sangat mengganggu dan menghambat peserta didik yang bersangkutan untuk meraih prestasi yang lebih tinggi, maka guru mengadakan perbaikan pembelajaran untuk meningkatkan hasil belajar IPA dengan mencoba menggunakan Strategi Pembelajaran Aktif Tipe Card Short. Alternatif penerapan Strategi ini diharapkan dapat meningkatkan aktifitas belajar peserta didik yang berdampak pada peningkatan hasil belajar IPA tersebut.

Hasil belajar adalah kemampuankemampuan yang dimiliki peserta didik setelah ia menerima pengalaman belajarnya. Berikut ini adalah beberapa definisi tentang hasil belajar menurut beberapa tokoh, antara lain:

a. Menurut Mulyono Abdurrahman "Hasil belajar adalah kemampuan yang diperoleh anak setelah melalui kegiatan belajar."

b. Oemar Hamalik dalam bukunya "Proses Belajar Mengajar" mengemukakan bahwa "tingkah laku manusia terdiri dari sejumlah aspek diantaranya pengetahuan, pengertian, kebiasaan, ketrampilan, apresiasi, emosional, sikap dan lain-lain. Hasil belajar akan tampak pada setiap perubahan aspekaspek tersebut.

Dalam sistem pendidikan nasional, baik tujuan kurikuler maupun tujuan instruksional, menggunakan klasifikasi hasil belajar dari Benyamin Bloom yang secara garis besar membaginya menjadi tiga ranah menjadi ranah kognitif, afektif dan psikomotorik.

Hasil belajar merupakan hasil dari suatu interaksi tindak belajar dan tindak mengajar. Bagi guru, tindak mengajar diakhiri dengan proses evaluasi hasil belajar. Bagi peserta didik, hasil belajar merupakan puncak proses belajar.

Jadi, hasil belajar merupakan perubahan tingkah laku secara keseluruhan yang telah dimiliki oleh seseorang. Perubahan tingkah laku tersebut menyangkut perubahan tingkah laku kognitif, afektif dan 
psikomotorik. Hasil belajar merupakan kemampuan-kemampuan yang dimiliki seseorang setelah ia menerima pengalaman belajar.

Sedangkan dalam menunjang peningkatan hasil belajar perlu dilakukan penerapan pembelajaran aktif card sort. Strategi belajar aktif dimaksudkan untuk mengoptimalkan penggunaan semua potensi yang dimiliki oleh peserta didik, sehingga semua peserta didik dapat mencapai hasil belajar yang memuaskan sesuai dengan karakteristik pribadi yang mereka miliki. Selain agar tetap tertuju pada proses pembelajaran. Silberman (2006:7) mengemukakan bahwa: Yang dapat membuahkan hasil belajar yang berkelanjutan hanyalah kegiatan belajar aktif. Agar belajar menjadi aktif, peserta didik harus mengerjakan banyak tugas. Mereka harus menggunakan otak untuk mengkaji gagasan, memecahkan masalah dan menerapkan apa yang mereka pelajari. Belajar aktif menyenangkan dan bersemangat.

Menurut Silberman (2006:11) mengemukakan paham belajar aktif: Yang saya dengar, saya lupa. Yang saya dengar dan lihat, saya sedikit ingat.

Yang saya dengar, lihat, dan pertanyakan atau diskusikan dengan orang lain, saya mulai pahami. Dari yang saya dengar, lihat, bahas, dan terapkan, saya dapat pengetahuan dan keterampilan. Yang saya ajarkan kepada orang lain, saya kuasai.

Menurut Priyono (2006:32) ada beberapa alasan sehingga belajar aktif perlu diterapkan, yaitu:

a. Karateristik peserta didik, rasa ingin tahu merupakan modal dasar bagi berkembangnya sikap kritis. Imajinasi merupakan modal berpikir dan kreatif.

b. Hakikat belajar, belajar ialah proses menemukan dan membangun makna oleh si pembelajar terhadap informasi dan pengalaman yang disaring melalui persepsi, pikiran dan pembelajaran si pembelajar. Karateristik lulusan yang dikehendaki, agar mampu bertahan dan berhasil dalam hidup, lulusan yang diinginkan ialah generasi yang peka, mandiri dan bertanggung jawab.

Sanaky (2006:34), strategi belajar memilah dan memilih kartu (Card Sort) adalah strategi dan metode belajar dengan cara memilah dan memilih kartu (Card Sort) dengan tujuan dari strategi ini adalah untuk mengungkapkan daya ingat (recoll) terhadap materi pelajaran yang telah dipelajari peserta didik. Kemudian Hartono menyatakan kartu sortir (Card Sort) adalah suatu kegiatan kolaboratif yang bisa digunakan untuk mengajarkan konsep, penggolongan sifat, fakta tentang suatu objek, atau mengulangi informasi.

Menurut Silberman (2002:9) strategi belajar aktif tipe Card Sortadalah kegiatan kolaboratif yang bisa digunakan untuk mengajarkan konsep, penggolongan sifat, fakta tentang suatu objek, atau mengulangi informasi. Gerakan fisik yang diutamakan dapat membantu untuk memberi energi kepada kelas yang telah letih.

Langkah-langkah pembelajaran dengan strategi belajar aktif tipe Card Sort, yaitu:

a. Peserta didik dalam kelas dibagi menjadi beberapa kelompok.

b. Masing-masing kelompok diberi kartu induk dan kartu rincian yang berisi materi.

c. Kemudian kelompok tadi berusaha mengurutkan dan mengelompokkan kartu-kartu tadi berdasarkan kategori materi.

d. Setiap kelompok mempresentasikan hasil dari kerjasama kelompoknya.

e. Peserta didik dibantu oleh guru menyimpulkan pembelajaran yang telah dilaksanakan.

Kelebihan strategi belajar aktif tipe Card Sort: 
Sayuti

a. Dapat mengarahkan peserta didik yang merasa penat terhadap pelajaran yang telah diberikan.

b. Dapat membina peserta didik untuk bekerjasama dan mengembangkan sikap saling menghargai pendapat.

c. Pelaksanaannya sangat sederhana dan peserta didik mudah dalam mengelompokkan pokok-pokok materi sehingga mudah dalam memahami materi yang diajarkan oleh guru.

Kelemahan strategi belajar aktif tipe Card Sort:

a. Membuat peserta didik kurang aktif dalam berbicara atau menyimpulkan pendapat.

b. Membutuhkan persiapan dan media yang berupa kartu-kartu sebelum kegiatan berlangsung.

c. Apabila guru kurang bisa mengendalikan kelas maka suasana kelas akan menjadi gaduh.

Jadi, strategi belajar aktif tipe Card Sort adalah suatu strategi pembelajaran dengan memberikan masing-masing peserta didik dengan kartu indeks yang berisi informasi tentang materi pelajaran, kemudian meminta kepada peserta didik untuk mencari temannya yang mempunyai kartu dengan kategori yang sama, atau menyebutkan jenis kategori kemudian membiarkan peserta didik yang mempunyai kategori informasi yang sama untuk berkumpul dan membentuk kelompok. Selanjutnya membiarkan peserta didik untuk berdiskusi sebelum mempresentasikan informasi di kelas.

\section{Metode Penelitian}

Jenis penilitian pada penelitian ini adalah penelitian tindakan kelas. Penelitian dilaksanakan di SDN Ketawang Karay I Kecamatan Ganding kabupaten Sumenep yang berlokasi di desa Ketawang Larangan Kecamatan Ganding Kabupaten Sumenep. Subjek yang diteliti adalah peserta didik kelas II SDN Ketawang Karay I Kecamatan Ganding Kabupaten Sumenep semester 1 tahun pelajaran 2018/2019, dengan jumlah 14 peserta didik, yang terdiri dari 14 peserta didik laki-laki.

Jenis data pada penelitian ini berupa data kuantitatif diwujudkan dalam nilai yang diperoleh peserta didik yang diambil dengan cara memberikan tes evaluasi pada saat sebelum dan sesudah diadakan perbaikan. Data kuantitatif diperoleh dari hasil tes pada setiap siklus. Hasil tes ditulis dengan langkah - langkah sebagai berikut: a. Merekap skor yang diperoleh Peserta didik.

b. Menghitung skor komulatif dari tugastugas Peserta didik.

c. Menghitung skor rata-rata.

d. Menghitung prosentase.

Untuk menghitung skor rata-rata Peserta didik menggunakan rumus:

$$
\text { Mean }=\frac{\sum \times}{\mathrm{n}}
$$

Keterangan :

Mean $=$ nilai rata - rata

$\sum X=$ Jumlah seluruh Peserta didik

$\mathrm{n} \quad=$ Banyaknya Peserta didik

Untuk menghitung prosentase nilai ratarata Peserta didik menggunakan rumus:

$$
\mathrm{SP}=\frac{S K}{R} \times 100 \%
$$

Keterangan :

$\mathrm{SP}=$ Skor Prosentase

SK = Skor Komulatif

$\mathrm{R}=$ Responden

Hasil perhitungan prosentase nilai ratarata peserta didik dari tes ini kemudian dibandingkan antara pra siklus dengan siklus 1, siklus I dengan siklus II. Hasil tes ini akan memberikan gambaran mengenai peningkatan kemampuan belajar Peserta didik melalui strategi pembelajaran aktif tipe Card Sort dan media gambar. 
Seddangkan data kualitatif digunakan untuk menganalisis data non tes. Data kualitatif ini diperoleh dari data observasi dan pengamatan. Adapun langkah-langkah penganalisisaan data kualitatif adalah dengan menganalisis lembar observasi yang telah diisi saat pembelajaran dan mengklarifikasikannya dengan teman sejawat yang membantu dalam penelitian. Data pengamatan dilakukan pada saat pelaksanaan pembelajaran dari pra siklus sampai siklus 2 mata pelajaran IPA materi Tempat hidup makhluk hidup dengan menggunakan strategi pembelajaran aktif tipe Card Sort dan media gambar

Teknik pengumpulan data dalam penelitian tindakan kelas tidak jauh berbeda dengan prinsip pengumpulan data pada jenis penelitian yang lain. Teknik pengumpulan data merupakan langkah yang paling utama dalam penelitian, karena tujuan utama dari penelitian adalah memperoleh data. Data penelitian ini bersumber dari peserta didik kelas II SDN Ketawang Karay I dengan menggunakan strategi pembelajaran aktif tipe Card Sort. Dalam penelitian ini, teknik pengumpulan data yang digunakan antara lain tes dan observasi.

\section{Dokumen}

Metode dokumentasi adalah mencari data mengenai hal-hal yang berupa catatan, transkip, buku, surat kabar, majalah, prasasti, notulen rapat, agenda dan sebagainya. Ada bermacam-macam dokumen yang dapat digunakan dalam penelitian. Dalam penelitan ini, instrument yang peneliti gunakan adalah hasil dokumentasi dari pelaksanaan pembelajaran di SDN Ketawang Karay I dengan menggunakan strategi pembelajaran aktif tipe Card Sort.

Teknik pengumpulan data dengan dokumentasi ialah pengambilan data yang diperoleh melalui dokumen- dokumen penelitian. Metode ini dilakukan untuk memperoleh daftar nama peserta didik yang termasuk dalam subjek penelitian, data-data yang berkaitan dengan sekolah, mulai dari struktur organisasi, daftar nama peserta didik yang menjadi subjek, pengambilan foto-foto dokumentasi selama proses pelaksanaan siklus dan daftar nilai peserta didik pada mata pelajaran IPA.

2. Tes

Tes adalah serentetan pertanyaan atau latihan serta alat lain yang digunakan untuk mengukur keterampilan, pengetahuan intelegensi, kemampuan atau bakat yang dimiliki oleh individu atau kelompok. Tes yang digunakan dalam penelitian ini adalah tes tertulis. Peserta didik diberi tes tertulis pada setiap akhir siklus, untuk mengetahui keefektifan tindakan dengan mengacu pada indikator keberhasilan yang telah ditentukan.

Tes yang digunakan adalah ulangan dengan bentuk soal essay dengan jumlah soalnya 10 butir yang diberikan setiap akhir siklus. Test ini bertujuan untuk mengetahui hasil belajar peserta didik setelah dilakukan pembelajaran dengan menggunakan strategi pembelajaran aktif tipe card sort. Cara pengumpulan datanya yaitu, data hasil belajar diambil dari hasil evaluasi berupa tes yang diberikan peserta didik pada akhir siklus.

3. Observasi

Observasi sebagai teknik pengumpulan data mempunyai ciri yang spesifik karena tidak terbatas pada orang, tetapi juga pada obyek-obyek alam yang lain. Dalam penelitian ini, observasi atau pengamatan dilakukan untuk mengetahui aktifitas peserta didik selama proses pembelajaran. Observasi sangat penting dilakukan 
Sayuti

dengan sangat hati-hati agar data yang diperoleh benar-benar akurat. Dalam pelaksanaan observasi di kelas, observer yang mengamati aktivitas peserta didik dalam proses pembelajaran adalah rekan guru peneliti (teman sejawat).

\section{Hasil dan Pembahasan \\ Kondisi Awal}

Subjek penelitian adalah peserta didik kelas II SDN Ketawang Karay I Kecamatan Ganding Kabupaten Sumenep. Sebelum melaksanakan penelitian, peneliti melakukan observasi awal dengan dibantu teman sejawat yaitu pada tanggal 22 Agustus 2018. Berdasarkan hasil observasi tersebut diketahui bahwa masih ada beberapa peserta didik yang mengalami kesulitan memahami materi pelajaran IPA. Hal ini terlihat dari nilai tes formatif peserta didik pada mata pelajaran IPA dari 14 peserta didik kelas II masih ada 9 peserta didik yang belum tuntas (64\%).

Dengan hasil belajar yang diperoleh dari kegiatan pra siklus ini maka disimpulkan bahwa hasil belajar peserta didik masih rendah. Untuk itu perlu adanya perbaikan pembelajaran pada pertemuan berikutnya. Berdasarkan data hasil observasi yang diperoleh, peneliti merencanakan penelitian tindakan kelas pembelajaran IPA menggunakan strategi pembelajaran aktif tipe Card Sort untuk memperbaiki hasil belajar peserta didik.

\section{Siklus I}

Setalah guru mengoreksi dan menganalisa hasil pekerjaan peserta didik, dapat diketahui hasilnya pada tabel hasil belajar peserta didik mengerjakan soal formatif pada siklus I, yaitu:

Hasil Tes Formatif Siklus I

\begin{tabular}{|c|c|c|c|}
\hline No & Rentang Nilai & $\begin{array}{c}\text { Jumlah Peserta } \\
\text { didik }\end{array}$ & Persentase (\%) \\
\hline 1 & $31-40$ & 0 & 0 \\
\hline 2 & $41-50$ & 3 & 21 \\
\hline 3 & $51-60$ & 2 & 14 \\
\hline 4 & $61-70$ & 2 & 14 \\
\hline 5 & $71-80$ & 4 & 29 \\
\hline 6 & $81-90$ & 1 & 7 \\
\hline 7 & $91-100$ & 2 & 14 \\
\hline & Jumlah & 14 & 100 \\
\hline
\end{tabular}

Berdasarkan tabel diatas apabila dibuat berikut ini: bentuk grafik maka akan terlihat grafik

Persentase Hasil Tes Formatif Siklus I

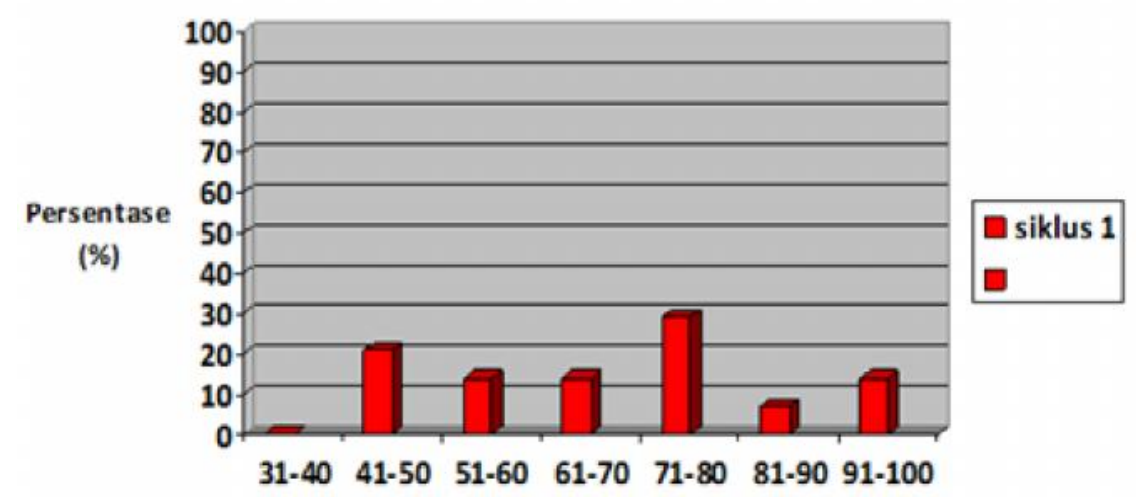


Berdasarkan tabel dan grafik di atas terlihat hasil tes formatif mata pelajaran IPA pada perbaikan pembelajaran siklus I dengan materi tempat hidup makhluk hidup di kelas II semester 1 menunjukkan bahwa masih banyak yang belum tuntas. Keadaannya adalah tuntas 9 peserta didik dan belum tuntas 5 peserta didik. Dari 14 peserta didik tidak ada yang mendapat nilai 31-40, 41-50 sebanyak 3 peserta didik (21\%), 51-60 sebanyak 2 peserta didik (14\%), 61-70 sebanyak 2 peserta didik (14\%), 71-80 sebanyak 4 peserta didik (29\%), 81-90 sebanyak 1 peserta didik (7\%), dan 91-100 sebanyak 2 peserta didik $(14 \%)$.

\section{Jumlah Ketuntasan Hasil Tes Formatif Siklus I}

\begin{tabular}{|l|c|c|}
\hline \multicolumn{1}{|c|}{ Nilai } & Jumlah Peserta didik & Prosentase \\
\hline Tuntas $\geq 70$ & 9 & $64 \%$ \\
\hline Belum Tuntas $<70$ & 5 & $36 \%$ \\
\hline
\end{tabular}

Persentase Jumlah Ketuntasan Hasil Tes Formatif Siklus I

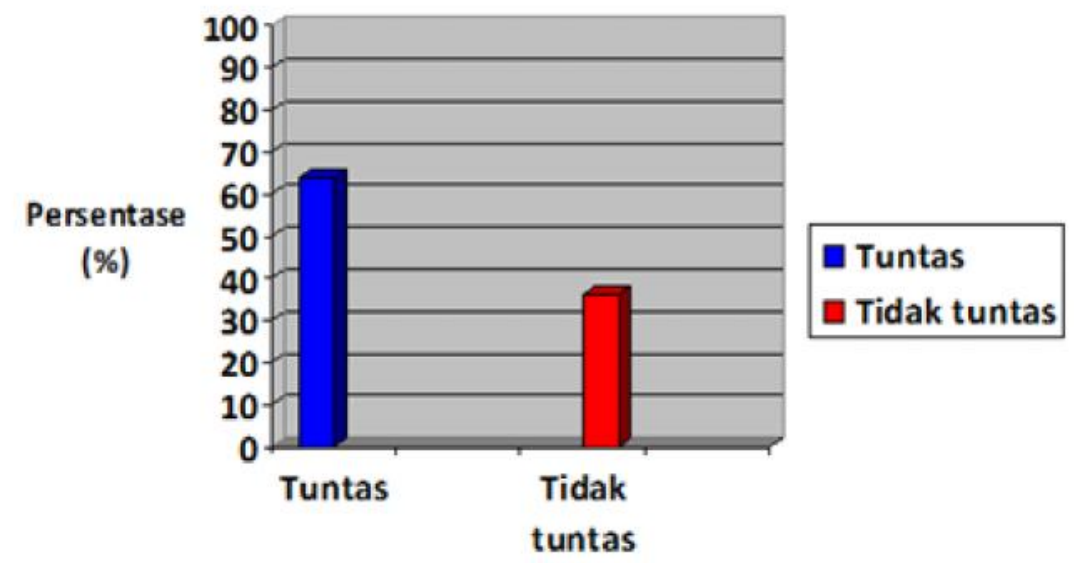

Pelaksanaan perbaikan pembelajaran siklus I mata pelajaran IPA pada tanggal 22 Agustus 2018, materi yang diajarkan adalah tempat hidup makhluk hidup diikuti oleh 14 peserta didik kelas II. Pertemuan ini berlangsung selama 1 x pertemuan $(2 \times 35$ menit).

Data dari tes formatif pada siklus I menunjukkan bahwa peserta didik yang memperoleh nilai $70 \mathrm{ke}$ atas pada mata pelajaran IPA sebanyak 9 peserta didik dari 14 peserta didik atau $64 \%$. Hal ini menunjukkan bahwa hasil belajar IPA pada siklus I belum memenuhi KKM yang diharapkan, maka perlu diadakan perbaikan pembelajaran di siklus II.

Pada perbaikan pembelajaran siklus I diperoleh hasil belajar peserta didik belum memenuhi kriteria keberhasilan yang ditetapkan. Berdasarkan hasil pengamatan peneliti terdapat beberapa hal yang perlu diperhatikan dari keseluruhan yang diamati yaitu :

a. Guru belum memberikan penguatan dan penekanan terhadap materi yang dipelajari

b. Guru belum memberikan kesempatan peserta didik bertanya dan menyimpulkan materi pelajaran

c. Waktu yang digunakan belum efektif karena masih ada peserta didik yang belum paham dengan strategi pembelajaran aktif tipe Card Sort

d. Persiapan pembagian kelompok banyak menyita waktu 
Sayuti

Pembelajaran yang kurang maksimal juga disebabkan oleh peserta didik itu sendiri, yaitu :

a. Peserta didik masih belum terbiasa dalam menggunakan strategi pembelajaran aktif tipe Card Sort

b. Peserta didik masih terkesan malu-malu dalam pelaksanaan strategi pembelajaran aktif tipe Card Sort

c. Pada saat pelaksanaan pembelajaran aktif tipe Card Sort masih ada peserta didik yang bermain sendiri tidak memperhatikan temannya yang sedang bermain Metode Card Sort

d. Masih ada peserta didik yang kurang memperhatikan ketika guru menjelaskan

\section{Siklus II}

Setelah guru mengoreksi dan menganalisa hasil pekerjaan peserta didik, dapat diketahui hasilnya pada tabel hasil belajar peserta didik mengerjakan soal formatif pada siklus 2, yaitu:

Hasil Tes Formatif Siklus II

\begin{tabular}{|c|c|c|c|}
\hline No & Rentang Nilai & $\begin{array}{c}\text { Jumlah Peserta } \\
\text { didik }\end{array}$ & Persentase (\%) \\
\hline 1 & $31-40$ & 0 & 0 \\
\hline 2 & $41-50$ & 0 & 0 \\
\hline 3 & $51-60$ & 0 & 0 \\
\hline 4 & $61-70$ & 3 & 21 \\
\hline 5 & $71-80$ & 3 & 21 \\
\hline 6 & $81-90$ & 3 & 21 \\
\hline 7 & $91-100$ & 5 & 36 \\
\hline & Jumlah & 14 & 100 \\
\hline
\end{tabular}

Persentase Hasil Tes Formatif Siklus II

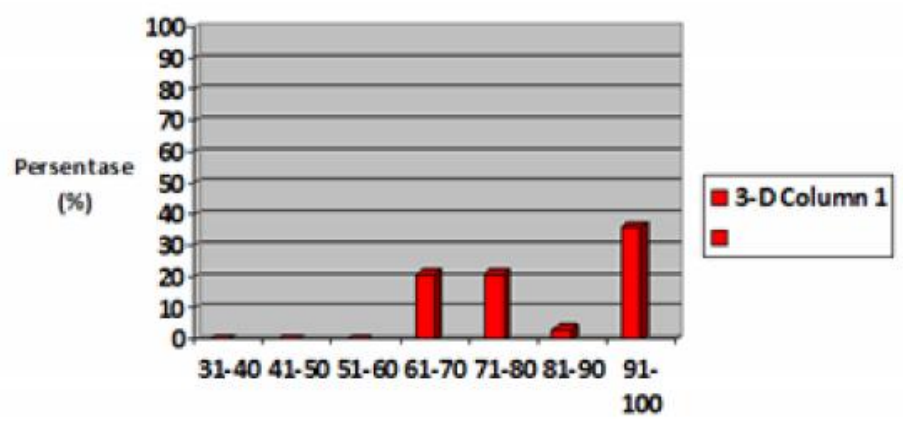

Berdasarkan tabel dan grafik di atas terlihat hasil tes formatif mata pelajaran IPA pada perbaikan pembelajaran siklus II dengan materi tempat hidup makhluk hidup di kelas II semester 1 menunjukkan bahwa hasil belajar peserta didik mengalami kenaikan. Keadaannya adalah semua peserta didik tuntas $100 \%$. Dari 14 peserta didik tidak ada yang mendapat nilai 31-40, 41-50, dan 51-60, 61-70 sebanyak 3 peserta didik (21\%), 71-80 sebanyak 3 peserta didik (21\%), 81-90 sebanyak 3 peserta didik (21\%), dan 91-100 sebanyak 5 peserta didik (36\%). 
Jumlah Ketuntasan Hasil Tes Formatif Siklus II

\begin{tabular}{|l|c|c|}
\hline \multicolumn{1}{|c|}{ Nilai } & Jumlah Peserta didik & Prosentase \\
\hline Tuntas $\geq 70$ & 14 & $100 \%$ \\
\hline Belum Tuntas $<70$ & 0 & $0 \%$ \\
\hline
\end{tabular}

Persentase Jumlah Ketuntasan Hasil Tes Formatif Siklus II

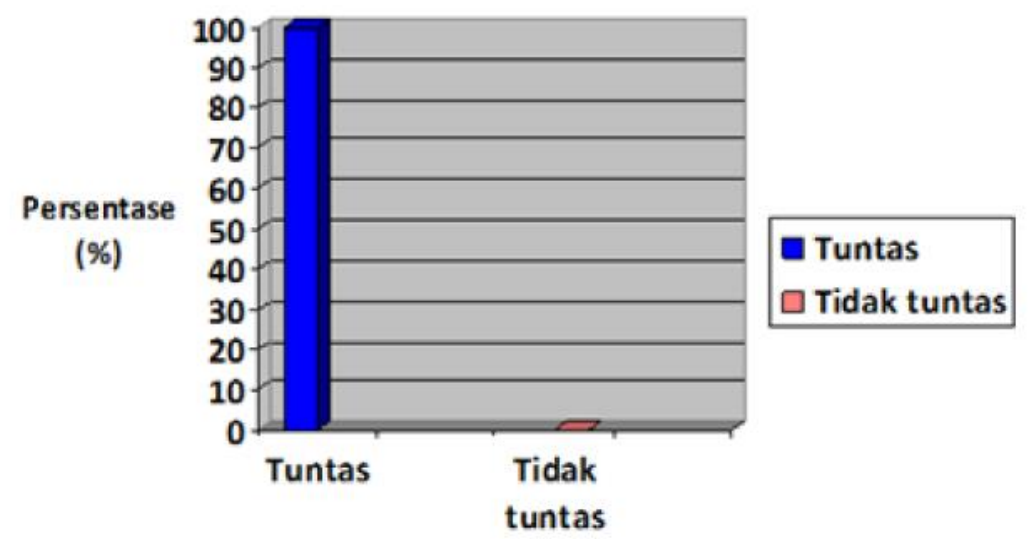

Grafik persentase jumlah ketuntasan hasil tes formatif mata pelajaran IPA siklus II dengan materi tempat hidup makhluk hidup di kelas II semester 1 di atas menunjukkan bahwa setelah diadakan tes, semua peserta didik dinyatakan tuntas $100 \%$. Sehingga hasil belajar peserta didik sudah mencapai indikator keberhasilan sebanyak $100 \%$ dari seluruh peserta didik kelas II SDN Ketawang Karay I Kecamatan Ganding Kabupaten Sumenep.

Pelaksanaan perbaikan pembelajaran siklus II mata pelajaran IPA dilakukan pada tanggal 5 September 2018, materi yang diajarkan adalah tempat hidup makhluk hidup diikuti oleh 14 peserta didik kelas II. Pertemuan ini berlangsung selama $1 \mathrm{x}$ pertemuan ( $2 \times 35$ menit).

Data dari tes formatif pada siklus II menunjukkan bahwa peserta didik yang memperoleh nilai 70 ke atas pada mata pelajaran IPA sebanyak 14 peserta didik dari jumlah peserta didik 14 peserta didik $100 \%$. Hal ini menunjukkan bahwa hasil belajar IPA pada perbaikan pembelajaran siklus II sudah memenuhi target dan sesuai KKM yang diharapkan, maka perbaikan pembelajaran pada siklus II ini dinyatakan berhasil. Adapun kelebihan dan kekurangannya antara lain sebagai berikut: a. Kelebihan

1. Aktifitas peserta didik dalam pembelajaran sudah berlangsung tertib dengan menggunakan strategi pembelajaran aktif tipe card sort

2. Meningkatnya hasil belajar peserta didik, baik nilai rata-rata maupun ketuntasan belajar peserta didik. Ketuntasan belajar peserta didik sudah mencapai $100 \%$ dengan ratarata tes formatif klasikal 87.

3. Peserta didik sudah terbiasa dalam menggunakan strategi pembelajaran aktif tipe Card Sort

4. Keberanian peserta didik meningkat dalam menggunakan strategi pembelajaran aktif tipe Card Sort

5. Pada saat pelaksanaan strategi pembelajaran aktif tipe Card Sort sebagian besar peserta didik memperhatikan temannya yang sedang bermain Metode Card Sort

6. Sebagian besar peserta didik memperhatikan ketika guru menjelaskan 
Sayuti

b. Kekurangan

Masih ada peserta didik yang belum aktif terlibat dalam proses pembelajaran tetapi jumlahnya sedikit, hanya 2 peserta didik. Namun masih bisa dikendalikan oleh guru.

Dalam perbaikan pembelajaran, sangat membutuhkan strategi pembelajaran yang sesuai dengan karakeristik materi pembelajaran. Untuk itu peneliti menerapkan strategi pembelajaran aktif tipe Card Sort.

Strategi belajar aktif tipe Card Sort adalah suatu strategi pembelajaran dengan memberikan masing-masing peserta didik dengan kartu indeks yang berisi informasi tentang materi pelajaran, kemudian meminta kepada peserta didik untuk mencari temannya yang mempunyai kartu dengan kategori yang sama, atau menyebutkan jenis kategori kemudian membiarkan peserta didik yang mempunyai kategori informasi yang sama untuk berkumpul dan membentuk kelompok. Selanjutnya membiarkan peserta didik untuk berdiskusi sebelum mempresentasikan informasi di kelas.

Berdasarkan hasil pengamatan pelaksanaan pembelajaran IPA siklus I sudah lebih baik dibandingkan dengan kondisi awal sebelum diadakan perbaikan. Namun masih ada beberapa peserta didik yang belum tuntas. Dengan demikian pembelajaran siklus I perlu diulang pada siklus II.

Sebagai bukti hasil tes formatif sudah menunjukkan peningkatan hasil belajar dari tahap pra siklus, siklus I dan siklus II secara urut adalah rata-rata klasikal peserta didik dari 47 pada tahap pra siklus meningkat menjadi 73 pada siklus I kemudian setelah mendapat perbaikan pada siklus II rata-rata klasikal meningkat lagi menjadi 87.

Dengan demikian, strategi belajar aktif tipe Card Sort dapat memicu keterlibatan peserta didik untuk aktif selama proses pembelajaran karena selama pembelajaran peserta didik diberikan masing-masing dengan kartu indeks yang berisi informasi tentang materi pelajaran, kemudian meminta kepada peserta didik untuk mencari temannya yang mempunyai kartu dengan kategori yang sama, atau menyebutkan jenis kategori kemudian membiarkan peserta didik yang mempunyai kategori informasi yang sama untuk berkumpul dan membentuk kelompok. Selanjutnya membiarkan peserta didik untuk berdiskusi sebelum mempresentasikan informasi di kelas. Hal ini menyebabkan pemahaman peserta didik lebih cepat dan hasil belajar peserta didik meningkat.

Hal tersebut diindikasikan oleh peningkatan ketuntasan belajar dari siklus I sebesar $64 \%$ meningkat pada siklus II menjadi 100\%. Sehingga tujuan perbaikan pembelajaran yang dilakukan dengan pola penelitian tindakan kelas dinyatakan berhasil.

\section{Kesimpulan}

Berdasarkan hasil perbaikan pembelajaran yang dilakukan melalui penelitian tindakan kelas (PTK) dapat disimpulkan yaitu:

1. Strategi pembelajaran aktif tipe Card Sort dapat meningkatkan hasil belajar peserta didik pada pembelajaran IPA materi tempat hidup makhluk hidup di kelas II SDN Ketawang Karay I Kecamatan Ganding Kabupaten Sumenep Semester 1 Tahun Pelajaran 2018/2019, hal ini dibuktikan dari aktifitas peserta didik yang aktif dalam pembelajaran karena selama KBM peserta didik diberikan masing-masing dengan kartu indeks yang berisi informasi tentang materi pelajaran, kemudian meminta kepada peserta 
ISSN 2548-9119

didik untuk mencari temannya yang mempunyai kartu dengan kategori yang sama, atau menyebutkan jenis kategori kemudian membiarkan peserta didik yang mempunyai kategori informasi yang sama untuk berkumpul dan membentuk kelompok. Selanjutnya membiarkan peserta didik untuk berdiskusi sebelum mempresentasikan informasi di kelas. Hal ini menyebabkan pemahaman peserta didik lebih cepat dan hasil belajar peserta didik meningkat.

2. Peningkatan hasil belajar peserta didik pada pembelajaran IPA materi tempat hidup makhluk hidup melalui strategi pembelajaran aktif tipe Card Sort di kelas II SDN Ketawang Karay I Kecamatan Ganding Kabupaten Sumenep Semester 1 Tahun Pelajaran 2018/2019, hal ini dapat dibuktikan dengan hasil yang diperoleh hasil belajar peserta didik selama kegiatan perbaikan pembelajaran yaitu pada pra siklus, kondisi hasil belajar peserta didik belum memuaskan baru terdapat $36 \%$ atau 5 orang peserta didik yang baru tuntas dalam pembelajaran dan sisanya 9 orang atau sekitar $64 \%$ peserta didik yang belum tuntas dengan rata-rata klasikal sebesar 47. Pada siklus I terdapat peningkatkan hasil belajar peserta didik yang cukup baik, dimana ada 9 orang peserta didik atau sekitar $64 \%$ yang tuntas dalam pembelajaran dan sisanya 5 orang peserta didik atau sekitar $36 \%$ peserta didik yang belum tuntas dengan ratarata klasikal sebesar 73 . Kemudian pada siklus II, hasil belajar peserta didik mengalami peningkatan yang sangat signifikan dimana terdapat 14 orang peserta didik atau $100 \%$ yang tuntas dengan nilai rata-rata 87.

\section{DAFTAR PUSTAKA}

Abdurrahman, Mulyono. (1999). Pendidikan bagi Anak Berkesulitan Belajar. Jakarta: Rineka Cipta

Arikunto, Suharsimi dkk. (2009). Penelitian Tindakan Kelas. Jakarta: PT Bumi Aksara. , (2002). Prosedur Penelitian Suatu Pendekatan Praktek. Jakarta: PT Rineka Cipta.

Baharuddin.2007. Teori Belajar dan Pembelajaran. Ar Ruzz Media Group: Yogyakarta

Hamalik, Oemar. (2007). Proses Belajar Mengajar, Jakarta: Bumi Aksara.

Mulyasa. (2006). Kurikulum yang Disempurnakan: Pengambangan Standar Kompetensi dan Kompetensi Dasar. Bandung: PT Remaja Rasdakarya.

S.Nasution. (2000). Berbagai Pendekatan Dalam Proses Belajar Dan Mengajar. Jakarta : Bumi Aksara.

Wahyudin, D., dkk. (2012). Pengantar Pendidikan. Jakarta: Pusat Penerbitan Universitas Terbuka.

Wardani, I.G.A.K. \& Wihardit, K. (2012). Penelitian Tindakan Kelas. Jakarta: Pusat Penerbitan Universitas Terbuka.

Wina Sanjaya. (2009). Penelitian Tindakan Kelas. Jakarta: Kencana 